\title{
RECONFIGURAÇÕES COLONIAIS: TRÁFICO DE INDÍGENAS, FUGITIVOS E FRONTEIRAS NO GRÃO-PARÁ E GUIANA FRANCESA (SÉCULOS XVII E XVIII) ${ }^{*}$
}

\author{
Rosa Elizabeth Acevedo Marin \\ Universidade Federal do Pará \\ Flávio Gomes \\ Universidade Federal do Rio de Janeiro
}

\begin{abstract}
Resumo
Durante os séculos XVII e XVIII interagiram, entre o Estado do Grão Pará e a Guiana Francesa, indígenas, escravos fugitivos, colonos, comerciantes, religiosos, administradores de França e Portugal. No artigo analisam-se as disputas entre os agentes coloniais e as ações e estratégias de pessoas comuns nessa fronteira.
\end{abstract}

\section{Abstract}

During 17th and 18th centuries, Indians, runaway slaves, settlers, tradesmen, religious, France and Portugal managers, have interacted in the territory. This article provides an analysis of the conflicts between colonial agents, the actions and strategies of common people in that boundary.

\section{Pallavras-Chave}

Fronteira • Escravos • Colonização • Grão Pará • Guiana Francesa

\section{Keywords}

Boundarie • Slaves • Colonization • Grão Pará • French Guiana

* Este artigo faz parte de pesquisas mais amplas que contam com apoio do CNPq. Os autores agradecem as leituras e comentários de João Reis, Jonas Marçal, Olívia Cunha e Maria Helena P.T. Machado. 
0

Estado do Grão-Pará compreendia um extenso território desde os primeiros anos da conquista colonial. Nele fixou-se uma ambição de domínio absoluto, materializada nos tratados e nas demarcações do século XVIII. No oeste instalaram-se os espanhóis que compartilharam, mais para o norte, uma faixa com os ingleses, holandeses e franceses. Segmentos dessas fronteiras constituíram uma rica invenção de sociedades multifacetadas, de horizontes históricos e culturais que se sobrepuseram e se alteraram por interferências externas e pela interação de grupos que ali conviviam. Essas fronteiras foram construídas e imaginadas conforme os interesses dos administradores de cada colônia em debater os limites territoriais e as formas de controle dos trabalhadores. A formação de sociedades e as experiências de grupos envolventes representam uma perspectiva mais complexa para quem ensaia interpretar a história social da fronteira, seus significados políticos e culturais, elaborados e transformados ao longo do tempo (Azevedo 1901; Farage 1991; Heming 1978 e 1987; Reis 1947, 1959, 1960 e 1966; e Salles 1971).

Neste estudo, a atenção dirige-se para a formação de comunidades de fugitivos, recuperando faces do tráfico de indígenas, redes do comércio clandestino, contrabando e, ainda, os mecanismos de poder e a violência exercida pelas autoridades sobre os atores que se moveram nestas fronteiras. Mesmo sem alcançar os contextos da ocupação portuguesa, das lutas de independência, dos movimentos de abolição da escravidão, o eixo é a vigilância que ocorre em cada margem; o que se focalizam são as contradições e as lutas de poderes locais. Nesse tecido social funcionavam regras que identificavam no dia-a-dia, o outro cultural, as práticas de solidariedade e de recusa da dominação social. O estabelecimento de locais, assim como os motivos para transgredir os códigos coloniais eram diferentes. Diversas práticas impuseramse, chegando até a desconhecer os limites geopolíticos e a ganhar certa autonomia.

As experiências de colonização nesta região das Guianas - relativas a quase dois séculos - estão registradas em uma documentação diversa. Neste artigo analisam-se as disputas durante a segunda metade do século XVIII entre agentes coloniais para controlar o território, realizar os projetos de colonização, evitar as fugas de escravos, disciplinar o comércio e resolver os atritos nas esferas de poder local. O propósito é focalizar, em uma etapa na construção das fronteiras, as ações de fugitivos, indígenas e dos próprios colonos, contrariando a força de governos numa área estratégica. 
A colonização da Amazônia oriental pode transmitir uma certa idéia de controle de todas as variáveis por franceses e portugueses; contudo, conflitos, expectativas, interesses e movimentação dos atores produzem visões menos comprometidas com um suposto princípio único e de racionalidade. Não raro prevalece a improvisação, o descontrole, o provisório, a prepotência de administradores que desviam e reordenam projetos de domínio colonial. As forças que movimentam os atores são analisadas como experiências históricas e não como uma estrutura inexorável ou um mundo mental à parte. Aqui o aprendizado resultou de um acúmulo e redefinição de experiências, incluindo as legais - na forma de tratados, acordos, códigos, leis - as militares - realizadas por meio de missões e de expedições - e as de pessoas comuns - que construíram relações sociais, formas políticas e culturais próprias (Alencastro 1992).

O historiador identifica com maior facilidade em registros históricos as estratégias de administradores e governos coloniais da França e de Portugal. Todavia, esse material não basta para acompanhar as ações das pessoas comuns, suas mentes e corpos, que em circunstâncias específicas conquistaram a independência dos seus atos em relação aos administradores, aos "maîtres", à religião e à moral civilizadora. Da parte dos governos, algumas decisões foram forçadas e outras realmente audaciosas, como a emancipação dos indígenas pelo ministério pombalino (1755), a expulsão dos jesuítas do Grão-Pará (1757) e da Guiana Francesa (1763), a primeira abolição da escravidão negra na colônia francesa (1794) e a tomada de Caiena durante nove anos pelas autoridades do Pará (1809-1817). Esses eventos, tanto quanto as guerras européias, repercutiram nesta região de Contestado e reforçam a necessidade de uma leitura menos linear, que só considera os limites físico-administrativos. Entendemos a fronteira enquanto campo de relações sociais, culturais e políticas renovadas, plena do movimento dos atores dessa experiência histórica, notadamente pelo contrabando e pela formação de comunidades de fugitivos. Daí a idéia de reconfigurações de fronteiras nos mundos coloniais e pós-coloniais.

Os contatos dos fugitivos e seus mocambos do Grão-Pará - a maior parte africanos, mas também alguns índios - com os franceses e com outros setores sociais atemorizavam e muito, as autoridades portuguesas. Na faixa do Contestado francolusitano existiram vários mocambos. Os mais conhecidos localizados às margens do rio Araguari. Os fugitivos atravessavam matas, cachoeiras, florestas, rios, montanhas e igarapés e buscavam escapar para outras colônias. Por isso estabeleciam seus 
mocambos justamente nas regiões de fronteira. E não era só uma opção pela ecologia local. Contavam com a ajuda de cativos das plantações, vendeiros, índios, vaqueiros, comerciantes, camponeses, soldados negros, entre outros. Em tal contexto, nessas fronteiras com as Guianas coloniais, negros, escravos fugidos, libertos ou livres, também indígenas e outros setores sociais, criaram, como veremos, um espaço para contatos e cooperação. Com expectativas diferentes, montaram um cenário de experiências transnacionais e estiveram atentos aos acontecimentos a sua volta. Misturavam-se fugitivos, cativos nas plantações e soldados desertores de ambos os lados, trazendo ou levando idéias, entre as quais percepções que redefiniam ou inventavam significados variados sobre escravidão, liberdade e colonização. Não ficaram impassíveis ou boquiabertos com as decisões políticas que lhes poderiam ser benéficas, nem com os desdobramentos dos movimentos de ocupação/colonização, nem permaneceram isolados na imensidão da floresta amazônica. Através de fluxo e refluxo constantes, conseguiram proteção e autonomia, mesmo que precária e temporariamente.

\section{Indígenas e africanos transitando em fronteiras}

Nos séculos XVII e XVIII, a faixa esquerda do rio Amazonas transformou-se num espaço de captura de indígenas para serem vendidos dentro e fora das Guianas por traficantes que partiam de Caiena. Nas suas andanças, os traficantes buscaram alargar suas zonas de atuação até rios e afluentes que estavam sob o domínio dos portugueses e onde mais facilmente se realizavam razias ou correrias de escravos. Na prática, estes traficantes de escravos foram os primeiros a rasgar boa parte desse território, descendo o rio Oiapoque até o Camopi, ou percorrendo o rio ApprouagueKaw. Isso antes que as sandálias dos missionários ou as botas dos colonos pisassem essas terras. As sucessivas tentativas da Guiana Francesa de organizar companhias e de executar projetos de colonização visaram resolver, de forma racional, o problema de escassez de trabalhadores, incorporando trabalho compulsório, através dos engagés, dos indígenas, obtidos por meio do tráfico e a escravidão africana. Os colonos de Caiena dirigiam-se a área do Contestado para traficar cativos indígenas, inclusive em regiões próximas das aldeias missionárias que reuniam os índios Palicour. Dessa forma, tais colonos desenvolveram várias iniciativas de ocupação desse território. Os escravos de origem africana eram raros e caros na Guiana. A escravização da mão-de-obra indígena, apesar dos riscos de confrontos com outros traficantes e da 
perseguição do governo português, abriu novas rotas e valeu-se de renovadas justificativas. Sociedades indígenas inteiras tinham desaparecido na Guiana e o tráfico não era proibido no Contestado e nas proximidades do rio Amazonas, lugares estratégicos por onde transitavam as canoas desses comerciantes ${ }^{1}$.

Tais questões motivaram atritos permanentes entre as colônias portuguesas e francesas desde a segunda metade do século XVII. Alguns destes foram parcialmente resolvidos, pelo menos legalmente, através de acordos ${ }^{2}$. A restituição de escravos de Caiena ou do Grão-Pará exacerbou, muitas vezes, hostilidades. Estas inevitáveis pela regularidade e pelo volume de apresamento de mão-de-obra. As relações entre os vizinhos continuaram sendo difíceis, apesar das diligências diplomáticas dos governadores nas Cortes. Um confronto em 1705 trouxe à luz uma dessas experiências. Três traiteurs saíram de Caiena para o Amazonas e forçaram os Aruans, que regressavam dessa região, a servir de "guias"; os indígenas reagiram e os mataram. Esse episódio provocou a desconfiança entre os franceses, que decidiram declarar guerra aos Aruans e vendêlos como escravos. Os jesuítas tomaram posição a favor dos índios e os teriam encorajado a desertar. Em um comunicado enviado à Corte, o governador Férolles expôs que os índios ficaram a favor dos portugueses, enquanto os jesuítas ameaçaram não dar a absolvição da Semana Santa àqueles colonos que comprassem os índios escravizados (Artur 2002:322). O ponto central desses atritos estava no controle das zonas de apresamentos de indígenas e na necessidade de abertura para o território lusitano onde se encontravam em maior número esses trabalhadores.

A escravidão dos índios no Grão-Pará apoiou-se em medidas dos governos metropolitanos que legitimaram a captura e estimularam o tráfico, embora tivessem decretado

\footnotetext{
${ }^{1}$ Cardoso (1984:177) e Marchand-Thébault (1986:14-15) comentam o tráfico de indígenas nas colônias francesas, proibido pela lei de 3/5/1739, sem dar maiores informações sobre seu desenvolvimento. Marchand-Thébault afirma que os índios foram sempre protegidos pelos missionários, pelo rei e pelos governadores, não obstante citar a guerra declarada por Férolles contra os Aruans e a sua transformação em escravos. Sobre as organizações de algumas micro-sociedades indígenas nestas regiões, ver: Dreyfus, 1993:19-41 e Whitehead, 1988. Arthur relaciona as nações indígenas desaparecidas na Guiana Francesa. (Ver: Artur 2002:239).

${ }^{2}$ No dia de São João de 1698 foi notificada a fuga de 60 índios das missões portuguesas que chegaram a Caiena. Os franceses os protegeram e lhes deram terras no rio Oyac. Outro episódio dois anos depois: quatro "traiteurs" franceses foram retidos pelos portugueses no Amazonas. Cf.: Artur, 2002:309-318.
} 
leis abolindo tais práticas temporariamente (1609 e 1680). A legislação definiu como cativos legítimos os índios aprisionados em guerra justa e os obtidos por meio de resgate. Em decretos de 1653 e 1655 o Estado procurou estabelecer as circunstâncias em que seria lícito aos "cristãos" declarar guerra justa se os índios impedissem a pregação evangélica, deixassem de defender as vidas e as propriedades dos colonos, estabelecessem alianças com os inimigos da coroa, impedissem o comércio e a circulação dos colonos, faltassem às obrigações impostas e praticassem o canibalismo (Farage 1991:27). A lei de 1680 aboliu toda e qualquer forma de escravidão dos índios. Esta determinação foi alterada em 1688 estabelecendo que a guerra justa defensiva aplicar-se-ia em caso de invasão dos estabelecimentos portugueses pelos índios ou quando estes impedissem a livre circulação de missionários e colonos. A modalidade de guerra justa ofensiva era admitida no caso de ameaça de ataque por parte dos índios. Além disso, as tropas de resgate - expedições realizadas para comercializar com tribos aliadas a arregimentação de mão-de-obra escrava - foram admitidas. Permitiu-se ainda a compra e venda, pelos portugueses, de prisioneiros de guerras entre as nações indígenas, incluídos os "índios presos a corda". Essa modalidade de escravidão foi a mais freqüente no período prépombalino. Na prática, o Estado tornou-se "empresário dos resgates" pois, por meio da venda dos escravos apresados pelas tropas oficiais, podia cobrar o dízimo. Essa atividade clandestina mobilizava os particulares e ampliou-se, desviando dinheiro dos cofres régios (Farage, 1991:28-29). Os conflitos entre portugueses e franceses acerca do cativeiro dos índios oscilavam de acordo com essas definições legais. Essa lei teve repercussões na Guiana Francesa onde se tinha notícia de escravos fugitivos entre os índios (Artur 2002:168, 176 e 179).

Depois de assinado o Tratado de Utrech (1713), os franceses empenharam-se em evitar o estabelecimento dos portugueses no rio Oiapoque, e para isso insistiram na ocupação de suas margens desde 1724. Tal localização era estratégica e considerada vantajosa para a instalação da capital da Guiana. O lugar facilitaria a chegada dos navios procedentes da França que ali encostariam primeiro do que em Caiena. De outro modo, a proximidade com o rio Amazonas representava outra vantagem, o que explica a insistência para criar estabelecimentos às suas margens (Artur 2002: 260). Esse tratado mobilizou ambos os governos no sentido de dirigir expedições à foz do Oiapoque. Os portugueses iam lá para identificar as marcas da investida dos rivais, e os franceses, os seus antigos marcos (Cardoso 1984: 51-52). Na região dos 
rios Oiapoque e Approuague-Kaw, localizavam-se as terras baixas de melhor qualidade da colônia francesa . As "terras baixas" ou pântanos costeiros são formadas por depósitos argilosos, seu nível sendo inferior em alguns decímetros ao de marés mais altas, de modo que são invadidas pelas águas marinhas até um máximo de cinco km em direção ao interior. Potencialmente férteis, a exploração era mais exigente em investimentos de capital, tecnologia e trabalho. A colonização do século XVIII avançou sobre as terras baixas do sudeste - região dos rios Approuague-Kaw, Oiapoque e Macouria. Nas terras baixas do rio Oiapoque, cultivavam-se café e cacau e, em zonas de terras altas, gêneros alimentícios de consumo diário, em maior quantidade.

Na parte mais setentrional do delta do Amazonas, que compreende a região de Macapá, os portugueses reconheceram excelentes terras agricultáveis. La Condamine descreveu essa área formada por uma grande planície que se estendia até a nascente do Oiapoque (La Condamine 1981:122). Nessa paisagem, observavam-se as ilhas formadas na boca do rio Amazonas, que constituíam, segundo o Pe. João Daniel, a "melhor porção de terras" de todo o rio para realizar o povoamento e o aumento das colônias. Eram terras próprias para a agricultura e "não deveriam ser acanhadas": algodão, mandioca, milho e, em especial, arroz. Ademais eram igualmente apropriadas à criação de gado bovino, para aproveitar as campinas (Daniel 1976).

O eixo de disputas - a região do Oiapoque - estava escassamente povoada na segunda metade do século XVIII, apesar das tentativas de uma presença francesa a oeste desse rio. O governo francês investiu, entre 1726 e 1728, vinte mil libras; militarmente procedendo à construção de um forte (1726) na entrada do rio para frear os portugueses. Havia duas companhias de soldados, às quais foram oferecida ajuda pecuniária, e se estimulou o casamento com as indígenas. Surgiram pequenos povoados com a presença de jesuítas (missão de Saint Paul, no rio Ouanary, afluente do Camopi e do Oiapoque), que chegaram em 1738 para converter os índios. Com a aplicação de mais dez mil libras, o governo francês esperava ampliar a colônia e realizar descobertas de minas de ouro, estabelecer um comércio com os portugueses e negociar com as

\footnotetext{
${ }^{3}$ Essas terras correspondem a $3.700 \mathrm{~km}$ da superfície da Guiana e as mais aproveitáveis encontramse a leste de Caiena. (Cf.: Cardoso 1984: 15-26). Uma visão política e científica desse assunto encontra-se no trabalho original de Guizan 1825.
} 
diferentes nações indígenas. Os religiosos das missões do Grão-Pará contribuíam, organizando as partidas "em segredo das canoas" de Caiena. Através da mediação dos mesmos, estabelecia-se a oferta de mercadorias francesas que eles reexportavam e ficavam aguardando o melhor momento para introduzi-las com segurança no Grão-Pará. Na região do Oiapoque, plantava-se cacau apesar das dificuldades de transporte, somente realizado por pequenas canoas que navegavam em águas acidentadas ${ }^{4}$.

Os portugueses haviam avançado nessa zona e levantaram um forte às margens do rio Araguari (1667). O tratado de 1700, assinado entre Portugal e França a propósito da fronteira do Oiapoque, determinou a demolição de fortificações, entre elas a do Araguari, para dar fim ao comércio entre os indígenas e os estrangeiros 5 . Posteriormente, os rumores de ameaça de invasão francesa, que não cessavam de chegar, levaram os portugueses a desenvolver uma rápida ação de reforço dos fortes militares e dos destacamentos em algumas aldeias do Amazonas. Em Macapá havia aldeias de franciscanos de Santo Antônio e de jesuítas para impedir que os franceses de Caiena viessem seduzir os índios. Nesse tempo, o "Regimento de Fronteiras" foi estabelecido com a atribuição de executar o plano de defesa das extremidades da capitania e de levantamento de fortes. Esse Regimento recebeu instruções de fiscalização. Os capitães da costa deviam percorrer o litoral entre a foz do Amazonas e o rio Oiapoque. Os lusos organizaram uma capitania militar que, além de destruir fortificações, feitorias e povoações dos inimigos, implantou uma política de terror para obter a submissão dos indígenas, também empregados na colheita de cacau nativo no rio Araguari (Castro 1999:139-162).

A formação da sociedade escravista na região do Oiapoque experimentou problemas para incorporar trabalhadores escravos de origem africana. Artur cita documentos que tratam do aumento lento do número de africanos na Guiana Francesa, desde o tempo dos holandeses. Os navios negreiros entravam muito irregularmente e, por longo tempo, o preço do cativo foi de 300 libras, muito elevado para os com-

\footnotetext{
${ }^{4}$ Segundo Artur (2002:455-458), nesse período, as exportações de cacau da região aumentavam em direção a Europa.

${ }^{5}$ Essa ordem foi anulada em 1701 e confirmada pelo artigo $\mathrm{n}^{\circ} 9$ do Tratado de Utrech. Esse forte estava "no rio Araguari, na boca dos seus lagos", posição que visava impedir o comércio de estrangeiros com os índios. (Cf.: Castro 1999:155).
} 
pradores locais. Soma-se a morte de 400 escravos durante a epidemia de varíola de 1716. Não fosse só isso, em toda a colônia, os roubos e as fugas de escravos preocupavam os administradores coloniais, que reforçaram o Code Noir com o artigo 39 (ordenança do rei de 10/7/1705), que penalizava os libertos que dessem apoio aos fugitivos com uma multa de 300 libras de açúcar. Na década de 1730, a fuga de escravos prisioneiros era facilitada pelos soldados que faziam sua guarda. Talvez houvesse conivência para algumas escapadas. Para os donos de habitation ${ }^{6}$, outro problema surgia com a obrigação de ceder escravos para trabalhos de construção e reforço das fortificações comandados pelo governador. Essas situações expõem o quadro que favorecia o contrabando de indígenas e a vigilância dos escravos africanos.

Com a execução de um novo projeto de colonização na Guiana (1763), buscavase superar o fracasso do núcleo situado em Kourou, nas antigas terras dos jesuítas. Ali teriam morrido mais de sete mil pessoas das dezesseis mil recrutadas na Alsácia, na Suíça e na Alemanha, o que trouxe péssima reputação à Guiana (Devèze 1965:1315). Esse projeto foi previsto para resolver o problema da mão-de-obra (Mam-LamFouck 1982:45). O ministro Choiseul havia enviado esse contingente de imigrantes, o mais elevado do Antigo Regime. A decisão significou a retomada da organização do tráfico de escravos negros, de maneira a apoiar explorações agrícolas rentáveis. A Guiana continuou aumentando sua população escrava africana. Segundo Artur, contava com 2.795 escravos em 1736, enquanto Polderman, que transcreveu os originais desse médico cita recenseamentos de 1737 indicando a existência de 4.413 escravos (Artur 2002:373 e 479). No período de 1765 a 1789, essa colônia recebeu mais 4.231 africanos, chegando a ter, no final desse século, quase dez mil escravos, concentrados na ilha de Caiena. No conjunto da colônia observava-se um crescimento importante de africanos escravizados, que representavam de 80 a $86 \%$ da população (Cardoso 1984:37, 46 e 48). A Guiana esteve, por algum tempo, à frente de projetos de colonização, entretanto, os passos dados na metade do século XVIII

\footnotetext{
${ }^{6}$ Os habitants constituíam o grupo de colonos franceses mantidos pela política de valorização das colônias do Cardinal Richelieu. Os primeiros colonos foram favorecidos pela "Companhia", que representava os interesses econômicos dos nobres, mas também dos militares e de ordens religiosas. A Companhia dos comerciantes de Rouen foi a primeira que se instalou e foi seguida pela Companhia do Cabo do Norte, que se instalou em Caiena.
} 
pelo Grão-Pará colocaram ambos no mesmo nível em termos de experiência de povoamento da área próxima do Contestado.

A colonização de Macapá teve início em 1751 no governo de Francisco Xavier de Mendonça Furtado, que transportou famílias de açorianos para dedicar-se ao cultivo de arroz e algodão. Esse projeto de povoamento ampliou-se com a criação de Mazagão, a vila Vistosa Madre de Deus e a aldeia de Santa Anna de Macapá (1765). Esta funcionou como reservatório de mão-de-obra indígena para os colonos e como campo de experimentação de uma administração laica, posteriormente elaborada na política do Diretório dos Índios, de 1757.

O Estado do Grão-Pará teve com a criação da Companhia Geral de Comércio do Grão-Pará e Maranhão, em 1755, a alternativa de suprimento de mão-de-obra africana. Essa companhia gozou do monopólio até 1777 e manteve-se com caráter de extra-monopólio até 1788, introduzindo um total de 31.317 escravos (Carreira 1983:51). Esses escravos vinham de Bissau, Cachéu, Serra Leoa, Cabo Verde e Angola. O incremento dessa mão-de-obra resolvia parcialmente as necessidades dos colonos, que dividiam os escravos com os agricultores do Maranhão (Dias 1970). Todavia, o africano era uma alternativa onerosa para os colonos descapitalizados do Grão-Pará. Na Guiana e no Grão-Pará o grosso dos colonos comprava o resto do carregamento dos escravos a preços idênticos aos pagos pelas elites, que escolhiam os melhores trabalhadores. Centenas de escravos foram revendidos na capitania de Mato Grosso e nas Minas Gerais, posto que o preço elevado dificultava sua aquisição local. Por isso Mendonça Furtado recomendava aos diretores da Companhia que, depois de deduzir seu "ganho lícito e honesto", reduzissem os preços dos escravos "a termos que fizesse tão bem conta aos moradores o comprá-los", e desta forma acostumar-se "a se servir com pretos, e a esquecer-se de alguma forma da sua amada escravidão dos índios". Reconhecia essa autoridade que o interesse por cativos índios era compartilhado pelos "moradores" e por "muita gente grande" (Carreira 1983: 32).

As regiões de fronteira não foram as mais povoadas por africanos. Do lado francês, a missão e a colônia de Oiapoque eram mal providas. Somente se mantinham em pé graças aos índios, conforme o registro da viagem de Joseph de Chabrillan (1742), que informava das guerras travadas entre os índios. Quase na metade do século XVIII, existiam apenas oito fazendas de franceses. Na região do Amapá, do lado luso-brasileiro, o crescimento do número de africanos foi também muito lento. 
Quando foi incrementada sua entrada, as colônias de Macapá, Mazagão e Vila Vistosa somavam 1.117 escravos, dos quais mais de 10\% pertenciam à Câmara Municipal .

\section{Traficados e fugitivos}

Durante a fase colonial, as tensões políticas propiciaram diversas situações de desconfiança entre autoridades, soldados, religiosos e famílias procedentes do GrãoPará e da Guiana ${ }^{8}$. Aumentavam as queixas das autoridades sobre a existência de cláusulas de tratados, não respeitadas, o que sugere a fragilidade das decisões das cortes. Além disso, o terreno de sua aplicação - as colônias americanas - estava saturado da morosidade e de práticas que mudavam de acordo com a situação concreta e os atores do momento. O tratado de junho de 1707 instruía sobre as modalidades de troca de prisioneiros entre portugueses e franceses. As instruções do rei da França de julho e novembro de 1712 reconheciam que Portugal havia deixado de executar esse tratado, que dava liberdade a todos os franceses e portugueses feitos prisioneiros em guerras travadas no mar. De outro modo, reconheciam igualmente a detenção em Lisboa e no Brasil de oficiais, soldados e marinheiros franceses por infração ao tratado. Nesse clima, os franceses adotaram atitudes de represália ${ }^{9}$.

As deserções de soldados eram freqüentes e os desertores enviados para trabalhar nas fortificações aproveitavam qualquer ocasião para fugir. Para as administrações, tratava-se de casos de indisciplina, de pessoas que agiam de forma semelhante aos escravos. A

\footnotetext{
${ }^{7}$ Conforme dados do "Mappa das famílias que a excepção dos índios aldeados se achavão existindo em cada huma da mayor parte das freguesias de ambas as Capitanias do Estado do Pará e de sua possibilidade e applicação no anno de 1778”, Arquivo Público do Estado do Pará, citados por (Acevedo Marin 1998: 68). ${ }^{8}$ Vários casos foram registrados. O padre Martin, um franciscano procedente do Pará e que passou pelo rio Oiapoque e Cunani, foi citado entre os suspeitos. A chegada de um português com sua família e escravos também foi objeto de sérias dúvidas: o recém-chegado estaria fugindo da ordem de prisão do governador por causa de um crime (Cf.: Artur 2002:658-661).

${ }^{9}$ Artur comenta que o Tratado de Utrech deveria ter sido anunciado solenemente por M. de Grandval aos holandeses e portugueses, e com isso as hostilidades deveriam ter cessado. Seu comentário descreve a miséria na qual se encontrava Caiena e a fraqueza para defender-se dos vizinhos "maîtres du pays au nord de l'Amazone et terres du Cap de Nord et conséquemment de la navigation de l'Amazone où les François ne pouvoient plus pénétrer, se tenaient tranquilles dans les terres qu'ils avaient occupées et qui leur furent cédées definitevement par le traité”. (Cf.: Artur 2002:372-373).
} 
indisciplina chocava as autoridades e aos proprietários de habitation. Por outro lado, os soldados de Caiena fugiam para o Suriname. Por esse crime estavam sujeitos à pena de morte, conforme decretos reais. Os soldados fugiam em situações criticas de fome, de castigos e de falta de pagamento de soldos. Por esse crime os prisioneiros estavam sujeitos à pena de morte. Os escravos e desertores da Guiana empreendiam a fuga na direção Caiena - Suriname, aproveitando o movimento dos ventos e das correntes. Os holandeses faziam a devolução e exigiam o pagamento das custas, que absorvia uma parte considerável do valor dos escravos (Artur 2002: 356, 357 e 375). Nesse caso, o tratado era dificilmente aplicado. Semelhante problema ocorria no lado do Grão-Pará.

Em relação ao tráfico e à fuga de indígenas e africanos, a diplomacia alimentava maiores suspeitas e desentendimentos. Autoridades produziram visões e práticas diferentes que, de forma sutil, mostram as contradições e os poderes locais envolvidos. O tráfico de cativos indígenas pelos franceses não respeitava os limites administrativos, enquanto os portugueses não estavam dispostos a acatar uma lei assinada pelos monarcas, que permitisse temporariamente o livre acesso de seus vizinhos ao Amazonas, como a lei de março de 1700. Quando os índios Aruans reagiram matando os traficantes, foram acusados de cumplicidade com os portugueses. Contrabandistas e traficantes utilizaram vários meios para capturar e escravizar os índios, mas buscaram também ter outros grupos indígenas do seu lado, como se depreende da fuga de sessenta índios aldeados às margens do rio Oyac. Os índios romperam violentamente com aquele grupo, quando se consideraram traídos.

Os tratados relativos à devolução dos índios serviram de modelo para os acordos subseqüentes. Em 1733, D. João V assinou um tratado para a extradição recíproca de fugitivos capturados, instruindo sobre isso os governadores do Grão-Pará. Esse documento confirmava as deserções em direção a Caiena e no sentido contrário de "escravos fugitivos em razão aos crimes que cometiam ou por espírito de libertinagem". O fato que gerou esse procedimento foi a reclamação de Jean Maranne Limouzin, morador de Caiena que viajou ao Pará para trazer de volta seus 12 escravos africanos e foi impedido de fazê-lo pelas autoridades portuguesas. Esse proprietário mobilizou o cônsul geral da França, em Lisboa. A devolução estabelecia como condição que os escravos recebessem o perdão pelos crimes cometidos, desta forma ficando sob a proteção do rei de Portugal, na expectativa de que o soberano francês agisse de forma semelhante. 
As expedições para trazer de volta a Guiana Francesa os cativos que fugiam para o Grão-Pará constituíam acontecimentos importantes e bem planejados. Essas viagens demoravam de três a quatro meses e eram organizadas com base no conhecimento dos territórios fronteiriços. À frente delas estiveram militares treinados, soldados, índios escravizados ou livres, muitos deles servindo de guias. A viagem de ida, os acidentes de percurso, a chegada e o recebimento pelas autoridades portuguesas, o retorno a Caiena e os resultados eram pormenorizados em relatórios de cada missão. A expedição de 1752 que teve à frente Duchassy, tenente da tropa, domiciliado em Rémire e proprietário de 22 escravos foi relatada por Artur. Nessa viagem fugiram índios e escravos, além de vários daqueles trazidos como recapturados (Artur 2002: 614-628).

É bom destacar que a situação na Guiana Francesa era alarmante na ocasião. Com o aumento do número dos cativos, as notícias de fugas e de formação de mocambos alcançaram uma freqüência preocupante para as autoridades. Os colonos da Guiana contavam com 8,6 escravos para cada branco (1789) e estavam agitados com o risco de fugas, além de revoltas de escravos com o poder de ir além de suas fronteiras. Em 1747, fugiram 50 escravos que pertenciam a cinco ou seis proprietários e buscavam escapar aos maus tratos (Artur 2002: 589 e 603). Na Montanha Plomb existia um mocambo que vinha se formando há alguns anos por negligência das autoridades, que talvez hesitassem em ordenar sua destruição. Uma revolta em 1749 levou à fuga de um grande numero e à formação de quilombos no meio da floresta (Artur 2002: 67). As fugas da Guiana Francesa para o Grão-Pará alcançaram notoriedade, fato até o presente insuficientemente estudado. Essas deserções colocavam na ordem do dia, como mencionado antes, a restituição dos fugitivos, gesto que passou a ser uma questão política desde os primeiros anos da colonização acumulando atritos freqüentes. Em 1734, o governador general do Estado do Maranhão dirigiu-se à Corte de Portugal para ter instruções sobre a restituição dos escravos de Caiena refugiados na sua jurisdição. O Conselho Ultramarinho defendeu uma posição categórica, acusando os franceses de acobertar os escravos e de não impor a "pena de morte" aos fugitivos. Esse Conselho recomendava enfaticamente ao governador-geral que tivesse todo cuidado e mandar examinar se os "franceses dão inteiro cumprimento às condições com que se lhe entregam os escravos". Exigia que os destacamentos encarregados de captura não ultrapassassem a margem meridional do rio Oiapoque ${ }^{10}$.

\footnotetext{
${ }^{10}$ Anais da Biblioteca e Arquivo Público do Pará (doravante ABEP), T. 6. Alvarás, Cartas Régias e Decisões. Lisboa, 16/3/1734. p. 208-209.
} 
Assim sendo, o referido tenente Duchassy foi enviado ao Grão-Pará com o objetivo de conduzir vários escravos fugitivos que estavam em Caiena. Viajou acompanhado de oito soldados, um sargento, trinta índios, escravos fugitivos do Pará e escravos domésticos, um total de 53 pessoas. Dois escravos indígenas desertaram nos primeiros dias de viagem. A maior parte dos índios da tripulação das canoas francesas era fugitivo das missões portuguesas. Vários escravos foram reconhecidos e reclamados pelos seus donos à chegada no Pará. Tratava-se de cativos indígenas e de origem africana que estavam sendo devolvidos e, chegando ao Pará, fugiram novamente. Duchassy somente recuperou um fugitivo que entregou a Francisco Xavier de Mendonça Furtado, governador do Grão-Pará e Maranhão. O representante de Guiana foi recebido com "politesse", entretanto, o governador manifestou inquietações sobre o verdadeiro motivo da viagem dos franceses, pois não podia acreditar que essa viagem, tão dispendiosa, tivesse sido feita unicamente para reclamar uma dúzia de fugitivos negros (Artur 2002: 624-625).

Os franceses de Caiena vieram receber "alguns pretos seus escravos que da dita colônia tinham fugido para esta Capitania (do Cabo do Norte)”, mas não castigaram os mesmos, que novamente empreenderam a fuga. No Grão-Pará, nesses casos, a prática era o bispo receber os escravos e ordenar sua distribuição entre os moradores $^{11}$. Havia duas versões para as fugas de escravos da Guiana: eles recebiam um tratamento rigoroso dos seus proprietários, o que provocava a insubordinação e a fuga; os colonos relaxavam o controle e acobertavam a sua fuga para o Grão-Pará ${ }^{12}$. Do rigoroso tratamento, há provas, começando pela aplicação do Code Noir. Em 1757, no Oiapoque, um escravo foi queimado vivo por ter elaborado um plano para

\footnotetext{
${ }^{11}$ ABEP. T. 4. Correspondência dos Governadores do Pará com a Metrópole. Carta dirigida por Francisco Xavier de Mendonça Furtado ao Rei de Portugal. Pará, 17/08/1755, p. 168-169.

${ }^{12}$ Marchand-Thébault escreve sobre o Code Noir e acrescenta informações sobre o controle por parte do Conselho Superior de Caiena para impedir que os senhores extrapolassem seu poder de correção. Fiedmont recebeu uma correspondência do rei solicitando que impedisse o "espetáculo revoltante de castigos públicos" e ao mesmo tempo pedindo a elaboração de um regulamento que poderia conduzir à moderação, impedindo os abusos do direito da correção e as demonstrações de crueldade em relação aos escravos. Esse regulamento foi aprovado em $1^{\circ}$ de janeiro de 1777 . A autora assinala que esses episódios de crueldade eram raros e acrescenta que eram "moins cruels que ceux pratiqués couramment dans les colonies voisines”. (Cf.: Marchand-Thébault 1986: 35-36).
} 
envenenar a sua senhora, junto com dois outros companheiros. Ele negava, dizendo que sua intenção era dar-lhe um pó para "torná-la boa, como também a sua irmã que morava junto". Em Caiena, os escravos tinham que se prover de alimentos, em desobediência ao Code Noir, que atribuía ao proprietário as despesas com alimentação dos seus escravos. Alguns documentos mencionam que havia poucas mulheres brancas e viúvas que ficavam à mercê dos seus escravos.

A insistência dos escravos em vir ao Grão-Pará leva à pergunta sobre o aliciamento de seus habitantes. Quais vantagens os fugitivos pensavam encontrar no Pará? Algumas pistas podem ser seguidas a partir de 1750. E vale a pena aqui reconstituir faces e fases deste contexto. As formas de escravidão indígena e africana assumidas pelas duas colônias ajudam a entender essas situações. Não se pode esquecer que a economia do Grão-Pará colonial era totalmente dependente do trabalho indígena. Os missionários deram provas de uma administração eficiente e lucrativa no sistema de aldeamentos. Por outro lado, fazendeiros do Grão-Pará declaravam não dispor de dinheiro para a compra de africanos que chegavam importados. Assim, continuavam a utilizar-se largamente do tráfico e da escravização dos indígenas (Cardoso 1984: 113) ${ }^{13}$. Os colonos reivindicavam da Corte uma medida que lhes disponibilizasse mais acesso à mão-de-obra indígena. A lei de 7 de junho de 1755, que extinguia a administração temporal das aldeias exercida pelos religiosos, provocou uma reviravolta econômica e política. O governador Mendonça Furtado convocou uma reunião da Junta das Missões, no Colégio da Companhia, onde fez o anúncio da lei. A partir desse momento, várias situações de conflitos e negociações ocorreriam. Poucos dias depois da promulgação, o bispo da diocese requereu a convocação dos Regulares para tratar ponto substancial: se os párocos assumiriam ou não essa posição nas aldeias e se ficariam sujeitos à jurisdição episcopal, no lugar dos Superiores da Ordem. Enquanto os capuchos, os mercedários e os carmelitas aceitaram a proposta, os prelados da Companhia de Jesus recusaram-na. Outro ponto importante foi a nomeação de diretores para as aldeias que deveriam receber a sexta parte do lucro líquido do comércio dos índios. Furtado tomou decisão e nela des-

\footnotetext{
${ }^{13}$ Sobre mão-de-obra indígena no Grão-Pará ver ainda: Azevedo 1901; Belloto 1982 e 1988; Farage 1991; Heming 1987; MacLachlan 1972 e 1973; e Sweet 1974.
} 
qualificou os índios por serem "ignorantes e rústicos”, sem capacidade de se autogovernar. Os diretores tinham a tarefa de ensinar os índios a comercializar seus produtos e cultivar as terras, portanto sua influência seria administrativa. As questões cruciais incidiam sobre os bens das aldeias. Depois de aprovada a lei, os missionários suspenderam as partilhas e os testamentos e os "mais interesses que pertenciam as escravidões dos índios". O governo temporal das aldeias e os mecanismos para reter os índios no trabalho era uma decisão crucial. Os índios recém-libertos estavam à deriva. o que provocava inquietações nos moradores e nas administrações. Não menos difícil era a condição dos mestiços, descendentes de africanos com indígenas ${ }^{14}$.

Alguns meses depois de declarada a liberdade dos índios, foi noticiada em Caiena a chegada de uma grande canoa que trazia 17 índios fugitivos que haviam procurado asilo em Caiena. O motivo da deserção foi a decisão do Diretor de castigar cruelmente até a morte o pai do chefe desses fugitivos. Essa vítima teria dito publicamente que queria fazer do crânio desse comandante uma cantoneira e dos ossos de suas pernas uma flauta, e isso porque tinha expulsado os religiosos das missões para estabelecer o governo dos seculares. A fuga do grupo foi antecedida da viagem do Pe. Martin, o jesuíta que buscou asilo em Caiena (Artur 2002:667).

A promulgação da lei por Mendonça Furtado levantou um redemoinho, embora o governador tivesse anunciado a proposta do Ministro Pombal desde sua chegada ao Grão-Pará. Os padres jesuítas teriam incitado os colonos das freguesias de Belém, descontentes com a alforria geral dos escravos indígenas, a enviar uma carta de Caiena ao Rei da França, oferecendo a essa autoridade a colônia do Pará. Os Jesuítas teriam sob seu mando 8.000 índios em todo o estado. Solicitavam os colonos que os franceses tomassem posse do Pará, mas que mantivessem a escravidão dos índios. O fato provocou a prisão daqueles que conspiraram contra Portugal. (Cardoso 1984:152).

Do outro lado da fronteira, o contexto também era de conflitos e instabilidade. $\mathrm{Na}$ Guiana Francesa, o fim da escravidão indígena ocorreu por volta de 1740. Existia um número pequeno de índios e escravizados. O decreto português de liberdade dos índios foi promulgado em uma fase de intensificação de fugas dos índios dos

\footnotetext{
${ }^{14}$ ABEP. T. 4. Correspondência dos Governadores do Pará com a Metrópole. p. 182-226. Sobre a mão-de-obra africana na Amazônia, (ver: Carreira 1983; MacLachlan 1973:112-145 e Salles 1971).
} 
domínios portugueses. Mittefeu, capitão das milícias francesas, dirigiu-se ao rio Mayacaré e entrou em contato com um grande número de índios fugitivos do lado português, convidando-os a estabelecer-se nas terras da França. Em 1753, esse oficial conduziu, entre homens, mulheres e crianças, 307 pessoas às margens dos rios Oiapoque e Approuague-Kaw. Os índios transformaram-se em peças importantes da ocupação do Oiapoque, que em 1751 tinha 73 "cabeças livres de todas as idades", 103 escravos e 23 habitations. A maioria das mulheres do Oiapoque era indígena (Artur 2002: 640 e 663).

Os escravos africanos e negros fugidos de Caiena procuraram nas margens de fronteiras do Grão-Pará a liberdade, pelo menos aquela que constituiriam com suas comunidades, trocas e integração a micro-sociedades indígenas e grupos de desertores que por ali perambulavam. Havia ainda a percepção política de que fugir para a fronteira e alcançar terras portuguesas era adquirir a liberdade. Uma notícia sobre 22 escravos negros fugitivos que se encontravam no Pará dava conta que eles ganhavam a vida trabalhando para quem os quisesse empregar. Pela legislação colonial eram livres na colônia portuguesa e usufruíam desse bem. Além disso, aquelas áreas de fronteiras transformadas no Contestado eram um campo minado onde ocorriam disputas de poder criadas pelos proprietários e pelas autoridades que estabeleciam um consenso em relação ao controle e enquadramento de trabalhadores. Do lado das autoridades, estava o comportamento das tropas envolvidas na captura de escravos e numa espécie de espionagem. A delação e a cumplicidade que favoreciam o outro no domínio colonial foram comportamentos reprovados. A delação aprofundava os perigos para a ordem interna e o medo da perda da segurança.

Um exemplo disso é o caso de um soldado desertor espanhol a serviço da Guiana Francesa que trouxe informações sobre um forte que estava sendo levantado, situado a apenas doze dias de Macapá, com um destacamento de 50 homens, e sobre outro de 25 homens com quatro peças de artilharia. $\mathrm{O}$ desertor espanhol esteve engajado na Fortaleza de Macapá onde foi diversas vezes interrogado sobre a construção do forte dos franceses no lago Amanari (Nogueira 2000). O serviço militar representava perdas para os homens recrutados. Francisco de Souza Coutinho, capitão general do Grão-Pará, estava preocupado com Macapá e a iminente invasão dos franceses. Numa correspondência dizia ao governador do Estado do Grão-Pará que mais de $50 \%$ dos soldados de Belém haviam desertado. Na comunicação do fato, aproveitou para solicitar 200 soldados para enviar a essa praça (Reis 1940:173-174). 


\section{Insubordinação, temores e mocambos}

Depois de 1755, as autoridades da Guiana Francesa sentiram concretamente as repercussões da abolição da escravidão indígena no Estado do Grão-Pará. A frequiência e o número de escravos fugitivos de suas fazendas tinham uma forte vinculação com a emancipação dos índios decretada por Mendonça Furtado. Acreditavam os administradores franceses que os portugueses tinham interesse em acobertar as fugas para resolver o problema de trabalhadores indígenas sobre os quais, eventualmente, tinham deixado de exercer o controle? Dois tratados foram assinados. O primeiro datado de 3 de março de 1732, restituía aos maîtres de Caiena os fugidos para a colônia portuguesa. O rei de Portugal acedeu a esse pedido, impondo uma condição: aqueles que por seus crimes tivessem recebido a pena de morte seriam perdoados e a restituição seria recíproca ${ }^{15}$. O segundo tratado, de 19 de setembro de 1762 retoma o tratado de restituição recíproca dos fugitivos entre ambas as colônias.

Os franceses queixavam-se de que houve da parte das autoridades do Grão-Pará pouco interesse em observar o cumprimento desses tratados. As reclamações constituíam processos cheios de filigranas, nos quais uma linguagem polida, que podiam parecer uma humilhação para os franceses de Caiena seria empregada, pois qualquer expressão descuidada, relativa aos vizinhos podia fazer fracassar o pedido de restituição. A autoridade francesa, M. Fiedmont escrevia que o governante de Portugal e todos os dessa nação pendiam entre o "glorioso e o deplorável" quando se tratava das fugas, mas que ele não teria uma única expressão para aqueles atos de proteção. Como parte dos seus vizinhos, suspeitava que os portugueses tudo faziam para desgostá-los e ao mesmo tempo enriquecer sua própria colônia, acarretando a ruína da Guiana. Era difícil para uma autoridade francesa tomar posição e deliberar, pois estava de permeio a vaidade dos franceses, dispostos a exigir seus escravos. Fiedmont, como homem político, optava por contemporizar para atingir o objetivo, sem que isto significasse humilhação, embora admitisse que o governo

\footnotetext{
${ }^{15}$ Houve contestação da cláusula sobre o perdão de criminosos pelas autoridades e pelos proprietários de escravos de Caiena. Cf.: (Marchand-Thébault, 41).
} 
português queria marcar sua superioridade em relação à Guiana. Autoridades e donos de habitation acompanhavam a reação dos escravos que alimentavam grande ódio por seus senhores e sabiam das facilidades para fugir para o Grão-Pará. O tratado estabelecia o castigo para os fugitivos. Contudo, o perdão outorgado pelo Rei de Portugal aos escravos restituídos os favorecia. Fiedmont exemplificava que um escravo que tivesse cometido um crime, como o assassinato do seu proprietário, poderia receber indulgência. Aqui se operava uma proteção que levava a novas fugas, posto que os fugitivos encontravam assim a segurança para "escapar a um justo castigo". Essas questões reaparecem em outros documentos com um tom de contestação das ingerências de Portugal. O aturdido administrador não podia resolver esse problema e ainda encarar, em 1767, uma espécie de motim, no qual estariam envolvidos escravos, no porto de Caiena, de onde se haviam afastado os barcos provenientes de Hamburgo, de Roterdam e da Índia.

A reclamação e a restituição dos escravos não constituíam uma operação fácil. Apesar dos discursos condenatórios recíprocos das autoridades de ambas as colônias, o movimento dos fugitivos continuava e enraizava-se por força dos interesses dos agentes envolvidos na sua manutenção. Tudo indica a existência de uma orquestrada proteção. Um novo período de fugas foi enfrentado em 1767. As autoridades francesas receberam várias reclamações dos donos de habitation que haviam visto seus escravos fugir para a "Amazônia dos portugueses" e queixavam-se aos portugueses, com base na Convenção de 1762. Fiedmont assinou uma correspondência em 14 de julho de 1767, na qual estranhava a mão única das fugas de Guiana em direção ao Grão-Pará e atribuía as fugas à lei de emancipação dos índios e os benefícios que tinham os portugueses com esse estado de coisas.

Existem várias informações detalhadas sobre a resistência escrava na Guiana Francesa. Cardoso sintetiza tais manifestações: "esprit de corps, defesa da margem de autonomia e da vida privada disponível (ou luta por sua ampliação), luta contra os capatazes e a disciplina, sabotagem do trabalho, roubos, uso inteligente da ironia, do sarcasmo e da superstição [...] fugas de escravos e constituição de quilombos". O historiador conclui que "antes da revolução não se registram revoltas de escravos" (Cardoso, 1984:63). Com base em alguns documentos de arquivos da Guiana Francesa, é possível rever essa afirmação e com cautela apresentar indícios da existência de um clima de insurreição sufocado em décadas anteriores. Em março de 1767 é 
produzido um relatório sobre a insubordinação dos escravos da colônia francesa ${ }^{16}$. Nele informava que os proprietários haviam visto morrer membros de várias famílias, de maneira que em Caiena se encontravam somente alguns velhos habitants e um grupo de mulheres que eram subjugadas por seus escravos. Os escravos, por diferentes meios, conseguiram armar-se com uma grande quantidade de fuzis e de pólvora que estava guardada em um barco. Esse processo de armamento vinha ocorrendo desde 1764, quando os escravos saíam a caçar por sua própria conta. Huyzier escrevia, por um "abuso pernicioso" os negros iam de habitation en habitation, a pretexto de algum serviço, e desta forma armaram uma conspiração, um plano coletivo para fugir em direção ao Grão-Pará, o Suriname ou qualquer outra parte da floresta. A colônia francesa não tinha homens suficientes para contê-los e faltava o controle dos proprietários ou da figura de um capataz para organizar o trabalho, dar punições e devolver os fugitivos aos seus proprietários. Mais adiante, informava sobre o que motivou a conspiração dos escravos. Certos rumores que corriam na colônia haviam despertado a insatisfação dos escravos. Segundo o Code Noir, os donos de escravos eram responsáveis pela subsistência dos escravos, como se continuava a praticar na Martinica e em São Domingos ${ }^{17}$. Entretanto, na Guiana, os proprietários, sem contar com recursos, cediam aos escravos o sábado para que cuidassem de suas roças e economia própria. Os colonos faziam as contas sobre as despesas com alimentação e vestuário. Os maîtres não davam nem alimentação, nem roupas a seus escravos, que em lugar de alimentos, recebiam álcool (tafiá). Não raro os escravos andavam nus pelas ruas. (Marchand-Thébault, 1986, p. 36) A nova disposição que obrigava os senhores a retirar o sábado, viria agravar a agricultura da colônia já afetada pelas fortes chuvas, pelo calor excessivo e pelas formigas e terras que não eram boas. Tudo isso expunha à fome os habitants da colônia.

\footnotetext{
${ }^{16}$ Arquivo Departamental de Guiana. C-14. Registro 34 , F ${ }^{\mathrm{o}}$ 273, 274, Caiena, 15/3/1767.

${ }^{17}$ O Code Noir, publicado por Luís XIV em 1685, estabelecia a disciplina da Igreja e do Estado em relação aos negros escravos nas ilhas da América. No artigo $6^{\circ}$, observava que os escravos não deviam trabalhar aos domingos, nem em dias de festa. Foi regulamentada a ração alimentícia e eram proibidos os tratamentos inumanos. Autores sublinham que o Code Noir foi estabelecido para atenuar as crueldades dos "maîtres blancs", mas não teve os meios de se impor à medida que ocorreram transformações materiais na sociedade "créole". Ver Bangou, 1989:17-20. Sobre a economia própria dos escravos na Martinica, (ver Tomich 1991: 68-91).
} 
Huyzier defendia a manutenção do sábado, pois convinha não somente aos proprietários, mas também aos escravos, entre outras coisas porque prendia os trabalhadores à terra e reduzia as fugas. Em relação à terra circulava outro rumor de uma decisão prestes a ser tomada sobre redistribuição das terras - o que, na opinião do militar (Huyzier tinha patente de Tenente) era muito delicado e geraria problemas entre os herdeiros dos primeiros colonos de Caiena. Nesse contexto, o número de fugas havia aumentado, talvez com o beneplácito dos habitants que assim podiam forçar uma tomada de posição ao seu favor. Huyzier ofereceu-se para viajar ao Pará e reclamar os escravos fugitivos. Demonstrava conhecer o terreno: o do lado português era diferente dos limites com a Holanda, não se encontrava sob vigilância, nem patrulhamento; não havia nenhum habitante, apenas os escravos fugitivos. Tudo indica que se tratava de grupos de escravos que haviam formado mocambos na fronteira.

As autoridades eram obrigadas a tomar conhecimento da situação e recebiam mensagens que exigiam a adoção de alguma medida com urgência. Apresentandose como cidadão e habitant de Caiena, Huyzier havia invocado seu direito de receber proteção ${ }^{18}$. Havia visto fugir três jovens escravos do seu plantel que, levados "pela libertinagem, fugiram para o Pará". Cobrava uma posição determinada por parte das autoridades e se valia de um argumento político. Segundo ele, os antigos governadores, como de Orvilliers, tiveram atitudes firmes para evitar as deserções e as fugas deploráveis que traziam maus exemplos para os escravos, incluindo os mais fiéis. Todos os proprietários pressionavam as novas autoridades.

Huyzier aproveitou para descrever a conspiração de março de 1767: os escravos faziam canções e organizavam festas nos domingos e acabavam reunindo escravos de várias propriedades. Com isso a idéia de fugir fermentava entre eles. Essa conspiração para uma fuga coletiva para o Pará foi chefiada por um mulato livre, empregado como ferrador e condenado à prisão. O documento não denuncia os nomes dos conspiradores para proteger a si próprio e aos outros donos de habitations que seriam arruinados com a reação dos acusados. A fragilidade da instituição escravista ficava patente. O escravo, em número cada vez maior para assegurar o lucro da colônia, também hipotecava a segurança do senhor de escravos, como bem frisou Bangou (1989:17).

\footnotetext{
${ }^{18}$ Arquivo Departamental de Guiana. C-14. Registro 34, Fo 273, 274, Caiena 15/7/1767.
} 
Qual era o sonho dos escravos fugitivos da Guiana? No Pará seriam livres e poderiam comer toda a carne que desejassem, acrescentava o tal Huyzier. Algo mais estava nos seus sonhos de liberdade: a autonomia de vida e trabalho nos mocambos juntos a fronteira e quiçá a "liberdade" das improvisadas ruas de Belém. Tudo isso e muito mais preocupavam autoridades portuguesas, francesas e proprietários de escravos. O militar recomendava aos governadores que reclamassem, como costumavam fazer. Deveriam assim, dirigir-se ao governo dos portugueses no Grão-Pará e acordar que nenhum escravo devolvido seria castigado. Huyzier, entretanto, defendia medidas de prevenção, como a venda dos restituídos a São Domingos e a destruição das raízes daquela conspiração. A idéia de venda em São Domingos serviria para cortar a onda de deserções, pois significaria a separação dos fugitivos de suas famílias.

A missão de Albanel de la Sablière, em julho de 1767, atendeu em apenas parte a essa solicitação. Com isso, Huyzier foi preterido na sua proposta. O capitão reformado Albanel, comandante das milícias do Oiapoque e o tenente de La Boulardière, das tropas nacionais, foram encarregados de se dirigir ao Grão-Pará com zelo, prudência e inteligência, devendo retornar com os escravos fugidos das habitations. Em longa digressão, M. Fiedmont le Maillard justificava a missão e o pedido de recursos para os gastos de viagem. Os dois militares receberam víveres, canoas e outros utensílios no armazém do Rei. Albanel teve a promessa de pagamento dos seus serviços. Seria dado um adiantamento de 1.200 libras e o restante no final da missão até completar a soma de três mil libras. Entre as instruções recebidas por ele constava ter uma grande cautela com os portugueses e não levantar a menor suspeita entre os escravos.

O propósito era capturar os escravos fugidos em diferentes tempos. O que significava buscá-los em seus próprios mocambos. A missão era uma expedição de captura financiada pelos franceses e se possível pelo governo do Grão-Pará. Nesse caso, abandonava-se a indicação dos tratados de setembro de 1732 e de 1762 . No aspecto legal, seria enviada uma carta ao cônsul francês em Lisboa, prevenindo-o da missão e solicitando que este expedisse uma carta ao governo do Grão-Pará pedindo o reembolso dos gastos. A missão Albanel definiu todos os seus passos, pois se tratava de uma petição secreta e temia-se uma reação negativa do Pará devido ao estado de guerra na Europa. Outra recomendação importante foi feita: caso a missão não tivesse êxito, sua viagem seria mantida em sigilo. Se escapasse qualquer palavra a respeito, os escravos alimentariam mais esperança de liberdade. Daí a reco- 
mendação de deixar no espírito destes uma dúvida, para evitar que continuassem a fugir com muita confiança ${ }^{19}$. A missão Albanel teve êxito, embora não total. O capitão trouxe consigo 26 escravos, quando o último anúncio de fugas coletivas indicava cinquienta indivíduos no Grão-Pará ${ }^{20}$. Quatro proprietárias receberam de volta seus escravos. Segundo a correspondência consultada, Albanel e La Boulardière foram bem recebidos no Grão-Pará, e as autoridades avisaram que, se ocorressem novas fugas, os escravos seriam postos a trabalhar na agricultura e ficariam empregados no serviço do Rei. A expedição de captura de Albanel atingiu um mocambo, mas outros se preservaram. O governo do Grão-Pará também teve êxito com a missão.

Mocambos no Grão-Pará - especialmente aqueles em áreas de fronteiras - não apenas se espalhavam e cresciam, mas também aperfeiçoavam suas estratégias de defesa. Noticiava-se, em 1749, haver no rio Anauerapucu "importante mocambo, cujos negros se internaram para o norte quando descobertos pelas expedições de resgate de índios". Em 1762, moradores de Arauari reclamavam que suas roças estavam sendo destruídas por escravos alojados em "grandes mocambos". Na região do Amapá, em 1779, era enviada uma expedição contra dois mocambos, um no rio da Pedreira e outro no Araguari ${ }^{21}$. Dos vários mocambos que se constituíram nas regiões de fronteira com a Guiana Francesa, aqueles que se formaram na área do Araguari foram, sem dúvida, os mais populosos e estáveis. Esses mocambos eram bem antigos, pois em 1762 já se comentava haver ali uma "grande soma" de fugitivos, tanto das povoações circunvizinhas como de outras mais distantes, alertando-se ainda que andavam "bem fornecidos de armas”. Em 1785, o governador do Grão-Pará informava sobre a necessidade de capturar ou dispersar escravos fugidos e mocambos, por meio de expedições militares, em várias partes ao longo do rio Araguari. Em 1788, alertar-se-ia, igualmente, para a

\footnotetext{
${ }^{19}$ Arquivo Departamental de Guiana. C-14. Registro 34, $\mathrm{F}^{\mathbf{o}}$ 107. Mission Albanel e La Boulardière. Caiena, 14/7/1767.

${ }^{20}$ Arquivo Departamental de Guiana. C-14. Registro 34, F 107. Mission Albanel e La Boulardière. Caiena, 14/7/1767.

${ }^{21}$ Cf. Muniz 1916: 389, citado em Salles 1971:221 e APEP, Códice 24, Ofício enviado ao Governador do Pará, 07/01/1762; Códice 214 (1782-1790), Ofício de Manoel Gonçalves Meninea enviado a Martinho de Souza e Albuquerque, 31/12/1788. Sobre mocambos ver também: (Gomes 1996 e 1999).
} 
existência de mocambos nessa região. Posteriormente chegaria a informação de que, nas cabeceiras daquele rio, mocambos tinham "um asilo seguro". Com grande "ousadia", grupos de fugitivos chegavam a se aproximar da cidade de Macapá, visando "desinquietar os escravos dos moradores para os seguirem".

Investigações trouxeram à tona os detalhes dessas experiências coloniais. A partir de um interrogatório realizado em Macapá, em 1791, revelava-se como os pretos dos dois lados da fronteira se comunicavam. O preto Miguel, escravo de Antônio de Miranda, vindo da "roça de seu senhor", encontrou o preto José, escravo do falecido João Pereira de Lemos, e este indagou se "queria ver e falar aos pretos que andavam fugidos". Miguel foi então conduzido até o curral onde se achava o preto Joaquim, escravo de Manoel do Nascimento. Logo foi avisado de que a "senha deles [habitantes dos mocambos] era chupar nos beiços”, como um assobio. Encontraram vários mocambeiros que, por não conhecerem o preto Miguel, estavam desconfiados e ameaçaram pegar "contra ele em arco e flecha". Começaram os primeiros contatos, querendo os mocambeiros saber "como passavam por cá", ou seja, na vila de Macapá, os negros escravos. Também o preto Miguel indagava "como passavam eles por lá", nos mocambos do Araguari e também nas fronteiras e terras dos franceses. Segundo os mocambeiros, "passavam muito bem", tinham "roças grandes e que os seus haveres os vendiam aos franceses porque com eles tinham comércio". No mocambo em que viviam também havia um padre jesuíta enviado pelos franceses e este era quem "os governava e que estavam muito bem de sorte". Naquela ocasião, parte dos habitantes do mocambo estava fora, pois eles "tinham partido a fazer uma salga para o seu padre e outros que havia pouco tempo que tinham acabado de fazer tijolos para os franceses fazerem uma fortaleza". Ainda segundo o preto Miguel, os mocambeiros "andavam sempre armados com seus chifarotes" e suas vestimentas eram "tintas de caapiranga". Por já haver temores e desconfianças, informações detalhadas como essas deixaram atônitas as autoridades do Grão-Pará.

\footnotetext{
${ }^{22}$ APEP, Códice 25, Ofício de 13/03/1762 e Arquivo Histórico do Itamarati (Doravante AHI), Documentação Rio Branco, Códice 340-1-3, Ofício de 08/07/1782.
} 
A questão, naquele momento, não parecia resumir-se em conter constantes fugas, vigiar espiões franceses e ouvir desaforos e reclamações de proprietários. Mocambos formados bem perto da fronteira mantinham relações de comércio com colonos franceses. Tinham igualmente sua base econômica, fazendo "salgas", tingindo roupas, plantando roças, pastoreando gado e fabricando tijolos para a construção de fortalezas francesas. Esses mocambeiros visitavam ainda a vila de Macapá na "festa do Natal". Vinham e estabeleciam contatos com vários escravos, mas "não vinham obrigar os pretos" a fugir, pois para o mocambo só "iriam os que quisessem ir por sua livre vontade". Revelaram "que o caminho por onde costumavam vir à vila já não era pelo flechal", mas sim próximo da "banda aonde Manoel Antônio de Miranda tem o curral para amor dos brancos que iam atrás deles". Além disso, tinham uma “canoinha no Rio Araguari, pois quando "vinham e iam” atravessavam "nela de uma para outra banda". Quanto aos contatos com colonos franceses: a "sua assistência era do Araguari para lá, mas que todos os pretos fugidos estavam da parte de cá". Ou seja, bem sabiam que mantinham suas habitações nas margens do Araguari em terras dos domínios portugueses, mas "para irem trabalhar a terra dos franceses atravessavam um rio de água salgada para lá irem e que iam pela manhã e vinham à noite", e "quando vinham deixavam metade do mantimento no meio do caminho para quando voltavam". E nesse mocambo habitavam "todos os pretos que desta vila [de Macapá] tem fugido",23. Estes mocambeiros eram também fugidos das habitations da Guiana Francesa? Podiam ser também escravos negros africanos que fugiam da construção de fortalezas portuguesas. A propósito, havia também reclamações das péssimas condições de trabalho de africanos ali e as fugas eram constantes. Décadas antes, em 1765, falava-se em 51 pretos fugidos, e no ano seguinte, oito destes fugitivos foram encontrados na costa de Araguari ${ }^{24}$.

A despeito das origens destes fugitivos nas fronteiras, se da Guiana Francesa ou do Grão-Pará - e inclusive não era impossível que grupos de negros africanos

\footnotetext{
${ }^{23}$ APEP, Códice 259, Auto de perguntas ao preto Miguel, escravo de Antônio de Miranda, 05/09/1791. ${ }^{24}$ APEP, Códice 58, Ofícios de 26/02 e 08/03/1765; Códice 70 (1766), Ofício de 15/05/1766; Ofício de 16/02/1765; Códice 76, Ofício de 20/01/1767 e Códice 77, Ofício de 25/01/1767. Sobre as fortalezas e a tecnologia militar na Amazônia Colonial, (ver Delson 1995: 555-574).
} 
de origens diversas tivessem se encontrado naquelas fronteiras - os detalhes das informações de como viviam os mocambeiros do Araguari são reveladores. Destacam estratégias e rotas de fugas, e mesmo a perspectiva desses mocambeiros de procurar autonomia e proteção. Viviam do lado da fronteira portuguesa, porém, comerciavam, trabalhavam e mantinham relações diversas com os franceses do outro lado. O sucesso dessa estratégia era diariamente garantido pela travessia da fronteira, tarefa que parecia não ser fácil. Cortavam rios e matas, levando, inclusive, mantimentos para longas jornadas. Esses mocambeiros estavam mesmo na fronteira da liberdade e sabiam disso. As autoridades portuguesas ficaram alarmadas ${ }^{25}$. Dois anos depois, o próprio Juiz da Câmara de Macapá chegou a propor que caso capturados, eles não fossem imediatamente soltos e entregues aos seus senhores. Na sua proposição, só deveriam sair da cadeia para "seus donos os venderem, o que devem fazer para diferentes países donde nunca mais aqui apareçam porque do contrário nos ameaça outra maior ruína, porque cada um destes escravos é um piloto para aqueles continentes" ${ }^{26}$.

Sobre os mocambos no Araguari informações mais detalhadas apareceram em investigações realizadas em 1792. Tudo começou com as costumeiras reclamações de fazendeiros e colonos quanto às fugas. Moradores da vila de Macapá estavam tão amedrontados com a freqüência das fugas que nem mais castigavam os escravos "nas suas costumadas rebeldias", tentando assim negociar a paz. Temiam fugas em massa. No início daquele ano, tinham sido capturados, no local chamado Baixa Grande, não muito distante da vila de Macapá, três pretos, sendo que um deles já

\footnotetext{
${ }^{25}$ Vale a pena comparar as experiências vividas por outras comunidades de fugitivos em áreas coloniais de fronteira no Caribe. As comunidades de maroons de Le Maniel, na Ilha de São Domingos, no século XVII, que travaram por quase cem anos lutas com os colonizadores espanhóis e franceses, foram beneficiadas, entre vários coisas, pela localização geográfica. Em diversas ocasiões, as autoridades espanholas deram pouca importância aos movimentos dos fugitivos, constituídos, na sua maior parte, de escravos do lado francês da Ilha. Os lavradores e fazendeiros do lado espanhol comerciavam com os negros fugidos e os mantinham informados sobre qualquer movimentação de tropas francesas enviadas para perseguí-los. Em conseqüência disso, a perseguição a esses grupos maroons envolveu inúmeros interesses de colonos e autoridades espanholas e francesas naquela área fronteiriça. (Cf. Debbash 1979: 144-145).

${ }^{26}$ APEP, Códice 259, Ofício da Câmara da Vila de Macapá, 21/02/1793.
} 
havia sido apreendido por ocasião de uma outra deserção sua. A prisão fora efetuada por alguns moradores acompanhados por seus escravos. Os fugitivos capturados confessaram que tinham a intenção de se reunir com vários outros da vila de Macapá e rumar "para o mocambo de seus parentes". Para isso estavam se preparando e haviam se refugiado em roças da vizinhança onde pretendiam "fazer toda a farinha que julgassem ser lhes bastante para a sua caminhada". Tais prisões e interrogatórios permitiram maiores investigações sobre os mocambos no Araguari. Entre as estratégias escolheu-se aquela de tentar simular a fuga de um escravo para que este conseguisse informações mais detalhadas sobre os locais dos mocambos. O autor da idéia foi o comandante militar Manoel Joaquim de Abreu. Para isso foi contratado um preto, chamado Manoel, escravo do morador Pedro Corrêa, para que "fosse indagar do escravo de Antônio Trez Orta por nome João, de todo o circunstanciado do mocambo e suas distâncias". As autoridades bem sabiam - ainda que não conseguissem extingui-las - das redes de comunicações entre os escravos e os mocambeiros naquela região. Enquanto o preto Manoel era considerado em Macapá um dos pouco "fidedigno e amigo dos brancos, e bons portugueses", o preto João era um elo de conexão importante "por ser o único que fugiu do tal mocambo, há mais de dois anos, porém sempre [estando] comunicando-se com os fugidos", quando estes retornavam à vila para comerciar, atacar moradores e realizar seqüestros ${ }^{27}$.

Para não suscitar desconfianças, aquela autoridade lembrava ao preto Manoel que ele deveria dizer a João que estava planejando sua própria fuga e, portanto, queria se "informar para melhor êxito". Em parte, tal estratégia trouxe resultados. João forneceria mais que a rota de fuga a Manoel, uma verdadeira descrição socioeconômica de um mocambo naquela área de fronteira. Revelou inicialmente que da vila de Macapá até a margem do rio Araguari, em termos de distância, se gastavamse quatro dias "a bom andar". Depois de atravessar este rio, ainda se andava durante mais dois dias, para então chegar ao mocambo. Os mocambeiros não conheciam "caminho algum pelo mar", visto "que nunca a isso se expuseram por ser muito longe, e os caminhos por terra lhe facilitarem a brevidade da jornada" do Araguari

${ }^{27}$ APEP, Códice 457, Ofício de 27/02/1792. 
até a vila de Macapá. O mocambo estava bem protegido. Primeiramente por uma barreira topográfica. Uma área cercada por rios e cachoeiras dificultava a aproximação de expedições punitivas assim como facilitava retiradas imediatas. $\mathrm{O}$ mocambo ficava na passagem do rio Araguari "acima da quarta cachoeira", na confluência de dois riachos. Apesar de não construírem "estacadas" e "trincheiras" comuns em muitos quilombos no Brasil Colonial - os mocambeiros cavaram fossos e colocaram "estrepes na circunferência da sua habitação" para impedir a aproximação dos reescravizadores. Também usavam armas: arcos, flechas, facas e "umas jardineiras [sic] compridas a forma de chifarotes" ${ }^{28}$.

Sobre a estrutura demográfica do mocambo, o preto João informou deveria ser composto de 100 pessoas, entre homens, mulheres e crianças, já que quando "veio embora ou aqui se escapou dos companheiros haveria lá perto de quarenta pessoas". Quanto às casas, eram de palha. As roças eram "somente" de farinha, milho e arroz, "sendo algumas destas em distância de mais de uma légua, e outras ao pé da sua habitação". Usavam "deste método para que se possam retirar as distantes, logo que suceda serem pelos brancos assaltados, e que lhe não possam resistir, porque como por várias vezes lhes têm queimado as casas, e roças, usam desta prevenção para terem a que se tornem". Estratégias de proteção e defesa combinaram-se com estratégias socioeconômicas. Estavam sempre de sobreaviso quanto às tropas repressivas. Sabiam da truculência e intolerância das autoridades para com suas economias. Mas não se mantinham isolados. Pelo contrário, alguns mocambeiros vinham até os povoados e mesmo à vila de Macapá, fazer contatos e realizar trocas mercantis. Com relação a isso tinham toda uma organização social. Segundo ainda o preto João, fugitivos incorporados recentemente ao mocambo de Araguari, eram proibidos pelos mocambeiros mais antigos de retornar à vila de Macapá. Só poderiam fazê-lo depois de mais de um ano de permanência no mocambo e após a permissão do "capataz", e isso em "companhia dos seus fiéis". Os antigos mocambeiros queriam evitar que membros mais recentes servissem de "correio" para denunciar a localização de seus acampamentos. Ao que parece, mesmo com todas as revelações do preto Manoel,

\footnotetext{
${ }^{28}$ APEP, Códice 457, Ofício de 27/02/1792.
} 
que supostamente planejava uma fuga, o preto João teria alertado: "te dou de conselho que não fujas, porque logo te matam, pois sabem que és muito camarada dos brancos, e não és da sua nação". E o preto Manoel - em "ficciosa preposição" - responderia: "eu sempre fujo, se me der bem, fico, quando não, torno a voltar e digo a meu [Senhor], que tenho andado perdido desde o dia que fui à caça" ${ }^{29}$.

Considerando tais informações, é possível analisar as estratégias políticas para evitar que os habitantes temporários dos mocambos capturados indicassem a sua localização às autoridades. O “capataz” do mocambo só dava licença para freqüentar a vila de Macapá para os moradores com mais de um ano. Habitantes temporários, ou seja, aqueles que viviam algum tempo nos mocambos e depois optavam por deixar tais comunidades, mesmo voltando para junto de seus senhores, eram vistos com desconfiança. Podiam ser aliados e fornecer contatos para os mocambeiros mais estáveis, porém, não raras vezes se transformavam em traidores e inimigos, uma vez que acabavam servindo de guias para tropas anti-mocambos. Pelo menos, nesse agrupamento de Araguari, percebe-se o poder de liderança de seu "capataz", com proibições e punição contra aqueles vistos com desconfiança. O preto João, que na ocasião dava todas as informações às autoridades, bem conhecia o poder dessa liderança. Durante o tempo em que conviveu no mocambo, viu que "o trabalho da caça e das roças é mandado fazer pelo capataz, e logo que se recolhem com a dita caça, ou efeitos da roça ou vão levar à presença do dito, o qual faz a repartição por todos eles". Em suas "revelações", o preto João confessou ainda que tinha "uma raiva muito grande" dos mocambeiros do Araguari, porque "também o quiseram matar". Além disso, quando vinham até a vila de Macapá, eles o convidavam para retornar ao mocambo, porém percebia que aquele convite era uma armadilha e "recomendação do capataz para cá o apanhar". Admitia que se guiasse qualquer expedição àquele mocambo, todos os seus habitantes seriam capturados, pois conhecia bem a localização das suas habitações, ainda que a tivessem mudado ${ }^{30}$.

\footnotetext{
${ }^{29}$ APEP, Códice 457, Ofício de 27/02/1792.

${ }^{30}$ APEP, Códice 457, Ofício de 27/02/1792.
} 
No Araguari provavelmente não havia somente um único quilombo. Deviam existir diversos grupos de fugidos espalhados em inúmeros pequenos mocambos. Um desses - talvez aquele em que o tal João morou temporariamente - tinha tamanho considerável, com dezenas de moradores. Não havia só diferença de tamanho. Podiam existir diferenças étnicas, sendo alguns mais antigos, outros mais recentes; uns só tinham africanos ou apenas determinados grupos étnicos africanos, como era o caso do mocambo acima designado como de "nação Benguela", enquanto havia outro "pequeno mocambo de mandigar", reunindo aqueles que se "ausentaram dos tais Benguelas há muito anos",

Os mocambos do Araguari continuariam preocupando as autoridades, principalmente do Grão-Pará. Nas últimas décadas do século XVIII, muitas denúncias chegaram às autoridades portuguesas: entre as cabeceiras do rio Araguari e em vários outros rios naquelas fronteiras "existiam as povoações dos pretos nossos de mais de 20 anos fugidos". Os mocambeiros acabariam atacados por tropas, mas conseguiriam escapar por terem sido avisados antes por franceses. Também havia muitos índios refugiados e desertores militares, muitos dos quais em permanente contato com os mocambeiros. Dizia-se haver "povoações" de índios refugiados de mais de 20 ou 30 anos, como no rio Anani e Cassipure. E no rio Uanary haviam "índios dispersos e pretos antigamente cativos em várias palhoças e ranchos" ${ }^{32}$.

Quase na virada para o século XIX, a questão dos mocambos e do movimento de fugitivos era tão grave que se pensou em utilizar grupos indígenas contra os mocambeiros. A idéia era "atrair um corpo de seiscentos a setecentos índios da nação mundurukus", considerada "a mais guerreira" da capitania do Grão-Pará e à qual depois de muitas guerras - as autoridades coloniais portuguesas tinham, pouco tempo antes, conseguido "reduzir à paz". Em termos de estratégias e recursos, entendia-se "que seria a gente mais própria para guerrear com pretos por entre matos e pântanos",

\footnotetext{
${ }^{31}$ APEP, Códice 457, Ofício de 27/02/1792.

${ }^{32}$ Biblioteca Nacional (doravante BNRJ), Códice 5, 1, 2 n. 2 (1791)

${ }^{33}$ Primeira Comissão Demarcadora de Limites (doravante PCDL), Códice A-44, Correspondência dos Governadores com a Metrópole (Regência de D. João VI, 1797-1799), Ofício de 29/03/1798.
} 


\section{Idéias atlânticas e significados locais}

Podemos pensar as áreas de fronteiras - as plantations - como espaços transnacionais. Se isso valeu para as estruturas, ainda que em geral sejam somente as econômicas, valerá também para a agência humana (Mintz 1988:117-133). Em fronteiras coloniais, nas últimas décadas do século XVIII, disputadas por interesses de Portugal e França, rumores, idéias e temores ganharam dimensões. Nessas regiões pululavam cada vez mais mocambos e fugitivos ${ }^{34}$. Havia uma grande preocupação por parte das autoridades coloniais. Como se tratava de uma região de fronteira, temia-se que os escravos fugissem dos domínios portugueses. Em 1795, o Governador Souza Coutinho admitia que havia fugitivos transitando sem dificuldade até as campinas de Macapá e que era "indispensável prevenir" tal "comunicação". Ponderava sobre a necessidade de dispor de barcos e vigiar postos da fronteira, dado o aumento das fugas, ainda mais "agora que em Caiena vão [os escravos fugidos] obter liberdade".

Na última década do século XVIII, autoridades coloniais ficaram sobremaneira sobressaltadas. Temiam que os cativos - principalmente aqueles sob o domínio português - entrassem em contato com "idéias perigosas" a respeito de revoluções, que chegavam da Europa e do Caribe através de Caiena. As principais fontes de "contágio" seriam a Revolução Francesa, a Revolução de São Domingos e as insurreições escravas (guerras maroons) da Jamaica e das Guianas. As autoridades coloniais portuguesas temiam em particular o impacto que poderiam causar nos escravos as notícias da Abolição nas colônias francesas e mais tarde na Venezuela, em função das lutas de independência na América Espanhola ${ }^{36}$. Declaravam-se explicitamente apreensivas quanto ao que os "franceses têm praticado nas suas ilhas, a respeito dos escravos”. O então governador do Grão-Pará, dois anos depois, relataria em detalhes ao Vice-Rei o pânico que rondava a fronteira. Mesmo assim, não acreditava

\footnotetext{
${ }^{34} \mathrm{O}$ estudo clássico sobre a escravidão negra na Amazônia continua sendo Salles 1971. Ver também Vergolino-Henry e Figueiredo 1990.

${ }^{35}$ APEP, Códice 272, Ofício de 20/11/1795 e Instituto Histórico Geográfico Brasileiro (doravante IHGB), Coleção Manoel Barata, Ofício de 10/01/1795.

${ }^{36}$ Carta do Governador Francisco de Souza Coutinho, 08/06/1795 transcrita em Reis 1947: 241 e Acevedo Marin 1992:35-40.
} 
que pudesse ocorrer uma invasão dos franceses. A seu favor, citava a própria insubordinação escrava que ocorria na colônia vizinha. Por precaução, mandou vigiar os navios vindos de Caiena e aqueles que navegavam o rio Cassipure ${ }^{37}$.

Como colonos, soldados, índios, negros, escravos e libertos viveram essa conjuntura? Reconstruíam episódios, contextos e temores com lógicas e expectativas próprias. O cotidiano e a leitura deste eram essencialmente politizados. Em meio às disputas coloniais entre Inglaterra e Holanda pelas Guianas, dizia-se, por exemplo, que alguns índios encontravam-se "influenciados por mulatos de Demerara", parecendo "satisfeitos da obediência ao atual governo inglês na colônia". Contatos e idéias transatlânticos que circulavam naquela conjuntura eram compartilhados tanto por negros como por índios. Povoações indígenas inteiras, por exemplo, cruzavam os territórios espanhóis em busca de refúgio. Em várias ocasiões, embarcações estrangeiras - sobretudo francesas - adentraram o território português, visando perseguir e recuperar fugitivos. Autoridades e fazendeiros portugueses denunciavam, igualmente, que seus escravos refugiavam-se em Caiena, onde encontravam proteção junto a comerciantes e autoridades francesas. Em 1798, a chegada à cidade de Belém, no Grão-Pará, de duas embarcações provenientes de Caiena, com o objetivo de "recrutar" os pretos que se achavam refugiados, foi acompanhada de grande tensão. Possibilidades de propaganda revolucionária e rumores de insurreição estavam em foco. Noticiava-se também com suspeição, a presença de franceses, próximo ao Oiapoque. Receava-se que eles, assim como outros que cruzaram a região, agitassem os escravos dos domínios portugueses. Prontamente, determinaram-se investigações para verificar se "eles traziam livros, manuscritos ou folhetos". (Gomes 1999). O governador do Grão-Pará, em ordem secreta, recebia recomendações expressas para exercer "grande vigilância sobre todos aqueles indivíduos que por palavras ou por conciliábulos e especialmente pela manifestação dos falsos e desastrosos princípios, que têm infestado toda a Europa, poderem de qualquer modo desassossegar o Governo" (Baena 1969:232).

Acreditava-se naquele momento que as fugas - apesar de constantes - e os mocambos nas franjas de fronteiras internacionais poderiam ser controlados. Pior

\footnotetext{
${ }^{37}$ IHGB, Códice Arq. 1, 1, 4, Conselho Ultramarino, Vol. 4, fl. 184 e 185, Ofício de 03/04/1796.
} 
seriam sublevações comandadas por emissários estrangeiros e com a participação de indígenas e mesmo de brancos pobres. O alerta estava no seu grau máximo. Em 1791, as autoridades portuguesas, por terem descoberto um fortim com alguma artilharia e indícios da construção de outro, foram levados a crer que o objetivo dos franceses seria estabelecer "comunicação" em vários rios - alcançando o Amazonas - para abrir rotas comerciais com a Guiana Francesa. As autoridades portuguesas preocupavam-se tanto com as disputas por "domínios reais", com o controle do comércio e do contrabando, quanto com o fato de a região de fronteira "ser cômodo asilo dos desertores, e o mais seguro mocambo a que os escravos se recolhem" e com o perigo que "poderia ainda introduzir-se por aquela vizinhança, aquele maligno espírito vertiginoso, que os [franceses] têm desgraçadamente consumido" "38. Franceses fugitivos, mocambos e a circulação de "idéias sediciosas" em fronteiras internacionais eram vistos como uma mistura explosiva naquele contexto. Uma preocupação fundamental seria verificar "se com efeito se haviam introduzido, ou se havia quem introduzisse por qualquer modo as perniciosas máximas, e abominável doutrina, de que pudesse resultar conseqüência, que fosse necessário prevenir a tempo". Buscava-se menos prevenir um possível ataque dos mocambeiros do que tomar "mais oportunas e eficazes providências, para acautelar e impedir toda e qualquer comunicação destes habitantes com os daquela inquieta nação"

Era o tipo de surpresa que autoridades coloniais, proprietários de escravos, militares e a população esparsa de colonos não queriam ter. O que em algumas ocasiões poderia passar despercebido, sem provocar maiores preocupações, transformava-se, em outras, em motivo de histeria coletiva. Em março de 1795, as atenções voltaram-se para um "ajuntamento" de escravos e forros no coração da capitania do Grão-Pará. O ponto de encontro era a casa de um preto alforriado em Belém. Embora as investigações pouco revelassem, lembrava-se que não era tempo para brincadeiras, visto que os "escravos não ouviam com indiferença o que se passava nas colônias francesas" e que devido a isso "saíam diversas vozes próprias a excitar

\footnotetext{
${ }^{38}$ Arquivo Histórico do Itamaraty (doravante AI), Documentação Rio Branco, Códice 340-1-3, Ofício de 01/03/1791.

${ }^{39}$ AI, Documentação Rio Branco, Códice 340-1-3, Ofício de 08/07/1792.
} 
desordem". Destacava-se que daquele "ajuntamento", além de escravos também participavam forros, "muitos dos mais conhecidos na cidade pela sua esperteza"

Definitivamente, a maré junto a esta margem atlântica estava agitada. Subestimar as percepções e experiências que os escravos podiam ter desta situação (e de outras) foi mais uma opção da historiografia do que de colonos e colonizadores. Ao mesmo tempo em que diziam que os cativos podiam ser "contagiados" pelas "idéias de liberdade" advindas da Europa, através de comunicações com as colônias estrangeiras, as autoridades temiam que ligado a isso, os escravos articulassem uma grande revolta. Assim, em 1794, um comandante militar de Araguari, próximo de Macapá, afirmou: "pelo que respeita a alforria dos escravos em Caiena, já eu tinha espalhado ser engano que os franceses fazem o mesmo aos pretos". Deste modo "para que lhes não fujam e os tenham por esta forma mais seguros para o serviço de suas lavouras, ou outros quaisquer a que os queiram aplicar, e por esta forma, ou por esta ironia eu conservo dúvidas da dita liberdade" ". É possível perceber aqui não só a visão que as autoridades tinham da situação, como também o uso político dela. Pode-se entender como escravos, fugitivos e desertores que perceberam as novas idéias, fizeram-nas circular e ao mesmo tempo trataram politicamente os medos que senhores e autoridades tinham desses fatos em vários contextos. Os escravos não precisaram, necessariamente, de um suposto "ideário revolucionário" advindo da Europa ou do brado de abolicionistas estrangeiros para implementarem seus protestos. Pelo contrário, poderiam perceber, avaliar e reconfigurar esses momentos com significados próprios.

Nos últimos anos do século XVIII, as autoridades coloniais portuguesas chegaram à conclusão de que o movimento de fugas nas fronteiras - justamente em função da provisória abolição nas colônias francesas e da propaganda libertária do Haiti - tinha adquirido outros significados. Num longo ofício, em 1798, seriam feitas várias avaliações. De início “o perigo senão maior pelo menos o que mais fácil, e mais prontamente se pode realizar é o de ficar esta Capitania em pouco tempo sem escravos, e também sem índios por se passarem sucessivamente para as terras de Caiena" ${ }^{42}$.

\footnotetext{
${ }^{40}$ Ver Gomes 1996: 40-55.

${ }^{41}$ APEP, Códice 214, Ofício de 16/01/1779 transcrito em Vergolino-Henry e Figueiredo, 1990:109-110.

${ }^{42}$ PCDL, Códice A-45, Correspondência dos Governadores com a Metrópole (Regência de D. João VI - 1797-1799) ofício de 03/02/1798
} 


\section{Considerações finais}

$\mathrm{Na}$ área das fronteiras orientais da Amazônia, mais do que em qualquer outra região no período colonial, fugas e o estabelecimento de mocambos aumentaram nos últimos anos do século XVIII. Havia outros problemas graves na região, entre os quais, sua militarização e o temor de uma intervenção armada estrangeira ${ }^{43}$. Em 1798, ano de muita tensão na fronteira com a Guiana Francesa, autoridades do Grão-Pará recomendavam aos moradores que armassem os seus escravos e se defendessem da "entrada do inimigo nas suas fazendas, e ainda nos rios, incorporando-se à força armada que neles existir para o mesmo fim". A idéia era "persuadir" os escravos a "concorrer para a defesa das suas propriedades e do Estado com eficácia, zelo, e valor assim como concorreram em outros portos do Brasil para expulsar os holandeses e franceses". Em relação aos colonos franceses, era preciso precaver-se "por conhecerem que as máximas de que estes têm usado só lhes têm servido para desunir as forças, fazerem as conquistas facilmente e roubarem tudo à sua vontade, pois até mesmo os seus escravos que enganaram com a idéia de liberdade, esses mesmos hoje os têm nas fazendas debaixo das baionetas, e de um regime tirano" ${ }^{44}$.

As autoridades coloniais, temendo uma invasão estrangeira, procuravam aliados entre seus próprios escravos. Era necessário transformar em amigos os "inimigos internos" para lutar contra os "inimigos externos". Entretanto, elas desconheciam ou subestimavam os significados políticos que os escravos podiam atribuir a suas ações naquele momento. Para as autoridades portuguesas, a colaboração entre negros escravos e forças invasoras estrangeiras era apenas fruto de "sedução" e inoculação de "idéias perigosas". Para os escravos, podia ser diferente. Podiam optar por lutar ao lado de seus senhores, barganhar algumas compensações por lealdade e continuar escravos. Uma outra opção seria fugir e engrossar as fileiras das forças inimigas. Lutariam por ou contra seus ex-senhores. Porém continuariam cativos, apesar de algumas falsas promessas. Mas havia ainda uma terceira alternativa. A fuga coletiva, formando quilombos, poderia garantir uma autonomia, pelo menos temporária.

\footnotetext{
${ }^{43}$ Cf. Acevedo Marin 1992.

${ }^{44}$ Ofício de 13/03/1798, Códice 259 do APEP, transcrito em: Vergolino-Henry e Figueiredo, 1990: 109-110.
} 
O estudo sobre as experiências coloniais e pós-coloniais nas áreas das Guianas permite refletir sobre as reconfigurações dos projetos e processos de colonização. E também numa perspectiva transnacional, especialmente nas regiões orientais amazônicas de fronteiras e disputas por franceses e portugueses. Em outras áreas e direções, diversas reconfigurações dar-se-iam e ainda merecem estudo, incluindo disputas com holandeses e espanhóis. Mais análises são necessárias sobre as expectativas dos vários setores coloniais. Destacamos as micro-sociedades indígenas e os seus movimentos de integração e rejeição a diversos movimentos e experiências de colonização e comércio. Avaliariam tudo nos seus próprios termos (Dreyfus 1993; Farage 1991 e Gallois 1994). Nas regiões de fronteiras com a Guiana, os movimentos de fuga - não só devido à quantidade e ao fluxo, mas também ao estabelecimento de mocambos nas fronteiras e a circulação de idéias - tiveram um papel fundamental nos próprios contornos de ocupação e colonização.

\section{Referências Bibliográficas}

ABEP. Annaes da Biblioteca e Arquivo Público do Pará. Pará: Tipografia do Instituto Lauro Sodré. 1910. T. VI.

ACEVEDO MARIN, Rosa. "Agricultura no delta do rio Amazonas: colonos produtores de alimentos em Macapá no período colonial”. In. ACEVEDO MARIN, Rosa. (org.). A escrita da história paraense. Belém:NAEA/UFPA, 1998. p.53-91

ACEVEDO MARIN, Rosa. A influência da Revolução Francesa no Grão-Pará, In: CUNHA, José Carlos C. da. (Org.) Ecologia, Desenvolvimento e Cooperação na Amazônia. Belém: UNAMAZ/UFPA, 1992. p. 34-59.

ALENCASTRO, Luiz Felipe. O aprendizado da Colonização. Revista do Instituto de Economia da Unicamp, no 1, p. 135-162. ago. 1992.

ARTUR, Jacques François. Historie des colonies françoises de la Guianne. Transcrito por Marie Polderman. Guyane: Ibis Rouge, 2002.

AZEVEDO, João Lúcio d'. Os Jesuítas no Grão-Pará, suas missões e colonização: bosquejo histórico com vários documentos inéditos. Lisboa: Tavares Cardoso \& Irmãos, 1901.

BAENA, Antônio Ladislau Monteiro. Discurso ou Memória sobre a Instrução dos Franceses de Cayenna nas Terras de Cabo Norte em 1836. Maranhão, Typographia da Temperança, 1846. Local e editora 
BAENA, Antônio Ladislau Monteiro. Compêndio das eras da Província do Pará. Belém: UFPA, 1969.

BANGOU, Henri. La révolution et l'esclavage à la Guadeloupe. 1789-1802. Paris: Éditions Sociales, 1989.

BELLOTO, Heloísa Liberalli. Política Indigenista no Brasil Colonial (1570-1757). Revista do Instituto de Estudos Brasileiros. São Paulo, nº 29, 1988.

BELLOTO, Heloísa Liberalli. Trabalho Indígena, Regalismo e Colonização no Estado do Maranhão nos séculos XVII e XVIII. Revista Brasileira de História. São Paulo: ANPUH, v. 2, n 4, 1982.

CARDOSO, Ciro Flamarion. Economia e Sociedade em áreas coloniais periféricas: Guiana Francesa e Para (1750-1817). Rio de Janeiro: Graal, 1984.

CARREIRA, Antônio. As Companhias Pombalinas de Grão-Pará e Maranhão e Pernambuco e Paraíba. Lisboa: Presença, 1983.

CASTRO, Adler Homero Fonseca de. O fecho do império: história de fortificações do Cabo Norte ao Macapá de hoje. In: GOMES, Flávio dos Santos (Org.). Nas terras do Cabo Norte: fronteiras, colonização e escravidão na Guiana Brasileira (séculos XVIII -XIX). Belém: Editora Universitária da UFPA, 1999. p. 133-200.

DANIEL, João. Tesouro descoberto no rio Amazonas (1757-1776). Rio de Janeiro: Biblioteca Nacional, 1976.

DEBBASH, Yvan. Le Maniel: Further Notes, In: PRICE, Richard (Org.). Maroon Societies. Rebel Slave Communities in The Americas. Baltimore, $2^{a}$ ed., Johns Hopkins University Press, 1979. p. 143-8.

DELSON, Roberta M. The Beginnings of Profissionalization in Brazilian Military: The Eighteenter Century Corps of Engineers. The Americas, v. 51, nº 4, p. 555-574, 1995.

DEVÈZE, Michel. Cayenne: Deportés et bagnards. France: Julliard, 1965.

DIAS, Manuel Nunes. A Companhia Geral do Grão Pará e Maranhão (1775-1778). Belém, UFPA, 1970. (Coleção Amazônica. Série José Veríssimo).

DREYFUS, Simone. Os empreendimentos Coloniais e os Espaços Políticos indígenas no Interior da Guiana Ocidental (entre o Arenoco e o Corentino) de 1613 a 1796. In: CASTRO, Eduardo Viveiros de; CUNHA, Manuela Carneiro da. Amazônia: Etnologia e história indígena. São Paulo: NHII/USP, FAPESP, 1993. p. 19-41.

FARAGE, Nádia. As muralhas dos sertões: os povos indígenas no Rio Branco e a colonização. Rio de Janeiro: Paz e Terra: ANPOCS, 1991. 
GALLOIS, Dominique Tilkin. Mairi revisitada: A Reintegração da Fortaleza de Macapá na tradição oral do Waiãpi. São Paulo: Núcleo de História Indígena e do Indigenismo, USP, FAPESP, 1994.

GOMES, Flávio dos Santos. Nas fronteiras da liberdade: mocambos, fugitivos e protesto escravo na Amazônia Colonial, In: GOMES, Flávio dos Santos (Org.). Nas terras do Cabo Norte: fronteiras, colonização e escravidão na Guiana Brasileira (séculos XVIII -XIX). Belém: Editora Universitária da UFPA, 1999.

GOMES, Flávio dos Santos. Em Torno dos Bumerangues: Outras Histórias de Mocambos na Amazônia Colonial. Revista USP, São Paulo, USP, v.1 no 28, p. 40-55, dez. 1995 jan./fev. 1996.

GUIZAN, M. Traité sur les terres noyées de la Guyanna appelées communément Terres Basses, sur leur dessechement, leur défrichement, leur culture et l'exploitation de leurs productions, avec des réflexions sur la Régie des Esclaves et autres objets. Cayenne, Imprimerie du Roi, 1825.

HEMING, John. Amazon Frontier. The Defeat of the Brazilian Indians. London: MacMillan,1987.

HEMING, John. Red Gold. The Conquest of the Brazilian Indians. Boston: Harvard University Press, 1978.

LA CONDAMINE, Charles Marie. Voyage sur l'Amazone. Paris: La Découverte, 1981.

MacLACCHLAN, Colin M. African Slavery and Economic Development in Amazônia (1700-1800). In: TOPLIN, Robert B. (eds). Slavery and Race Relations in Latin América. Greenwood Press, 1973. p. 112-145.

MacCLACCHLAN, Colin M. The Indian Directorate: Forced Acculturation in Portuguese América (1757-1799). The Americas, v. 28, nº 4, 1972.

MACLACHLAN, Colin M. The Indian Labor Structure in the Portuguese Amazon, 17001800. In: ALDEN, Dauril.. Colonial Roots of Modern Brazil. Berkeley: University of Califórnia Press, 1973. p. 228-82 (Papers of the Newberry Library Conference).

MAM-LAM-FOUCK, Serge. La Guyane Française du XVII siècle à 1960. Paris: Desormeaux, 1982.

MARCHAND-THÉBAULT, Marie-Louise. L'esclavage en Guyane sous l'Ancien Regime. In. MAM-LAM-FOUCK, Serge; BRULEAUX, A.; CALMONT, R. (Coords.) Deux siècles d'esclavage en Guyane Française (1652-1848) Paris: Harmattan ; Cayenne, CEGER, 1986. 
MINTZ, Sidney. The localization of Anthropological Practice. From area studies to transnationalism. Critique of Anthropology, v. 18, nº 2, p. 117-133, 1988.

MUNIZ, Palma. Limites Municipais do Estado do Pará (Município de Mazagão). Belém, 1916

NOGUEIRA, Shirley Maria Silva. Razões para desertar: institucionalização do exército no Grão-Pará no último quartel do século XVIII. Belém: folhas Dissertação (Mestrado), UFPA/NAEA/PLADES, 2000.

REIS, Arthur Cézar Ferreira. A Amazônia e a cobiça internacional. São Paulo: Cia Ed. Nacional, 1960.

REIS, Arthur Cézar Ferreira. A expansão Portuguesa na Amazônia nos séculos XVII e XVIII. Rio de Janeiro, SPVEA, 1959.

REIS, Arthur Cézar Ferreira. A política de Portugal no Vale Amazônico. Belém, 1940.

REIS, Arthur Cézar Ferreira. Aspectos da Experiência Portuguesa na Amazônia. Manaus, Governo do Estado, 1966.

REIS, Arthur Cézar Ferreira. Limites e Demarcações na Amazônia Brasileira. Rio de Janeiro: Imprensa Nacional, 1947.

SALLES, Vicente. O Negro na Pará, sob o regime da escravidão, Belém: FGV, 1971.

SWEET, David G. A Rich Realm of Nature Destroyed: The Middle Amazon Valley, 16401750, Tese (Doutorado). The University of Wisconsin, 1974.

TOMICH, Dale. Une Petit Guinée: Provision Ground and Plantation in Martinique, 18301848. Slavery \& Abolition, v. 12, $\mathrm{n}^{\circ}$ 1, p. 68-91, maio, 1991.

VERGOLINO-HENRY, Anaíza; FIGUEIREDO, Arthur Napoleão. A presença africana na Amazônia Colonial: Uma notícia histórica. Belém: Arquivo Público do Pará, 1990.

WHITEHEAD, Neil L. Lords of the Tiger Spirit. A History of the Caribs in Venezuela and Guyana, 1498-1820. Dordrecht: Foris Publications, 1988. 